\title{
Kinetic and structural studies reveal a unique binding mode of sulfite to the nickel center in urease
}

Luca Mazzei ${ }^{1}$, Michele Cianci ${ }^{2}$,Stefano Benini ${ }^{3}$,Leonardo Bertini ${ }^{l}$, Francesco Musiani $^{l}$, Stefano Ciurli ${ }^{*}$

${ }^{1}$ Laboratory of Bioinorganic Chemistry, Department of Pharmacy and Biotechnology, University of

Bologna, Via Giuseppe Fanin 40, I-40138, Bologna (Italy)

${ }^{2}$ European Molecular Biology Laboratory c/o DESY, Notkestraße 85, 22607 Hamburg, Germany

${ }^{3}$ Bio-Organic Chemistry and Bio-Crystallography Laboratory, Faculty of Science and Technology, Free University of Bolzano, Piazza Università 5, 39100 Bolzano, Italy

* Corresponding author: stefano.ciurli@ unibo.it; phone: (+39)-051-209-6204; fax: (+39)-051-209-6203 


\begin{abstract}
Urease is the most efficient enzyme known to date, and catalyzes the hydrolysis of urea using two $\mathrm{Ni}(\mathrm{II})$ ions in the active site. Urease is a virulence factor in several human pathogens, while causing severe environmental and agronomic problems. Sporosarcina pasteurii urease has been used extensively in the structural characterization of the enzyme. Sodium sulfite has been widely used as a preservative in urease solutions to prevent oxygen-induced oxidation, but its role as an inhibitor has also been suggested. In the present study, isothermal titration microcalorimetry was used to establish sulfite as a competitive inhibitor for $S$. pasteurii urease, with an inhibition constant of $0.19 \mathrm{mM}$ at $\mathrm{pH}$ 7. The structure of the urease-sulfite complex, determined at $1.65 \AA$ resolution, shows the inhibitor bound to the dinuclear Ni(II) center of urease in a tridentate mode involving bonds between the two $\mathrm{Ni}$ (II) ions in the active site and all three oxygen atoms of the inhibitor, supporting the observed competitive inhibition kinetics. This coordination mode of sulfite has never been observed, either in proteins or in small molecule complexes, and could inspire synthetic coordination chemists as well as biochemists to develop urease inhibitors based on this chemical moiety.
\end{abstract}

\title{
KEYWORDS
}

Urease, sulfite, nickel, crystallography, calorimetry, enzyme kinetics, Sporosarcina pasteurii 


\section{INTRODUCTION}

Urease (urea aminohydrolase, EC 3.5.1.5) is a nickel-dependent non-redox enzyme whose catalytic function is the hydrolysis of urea to yield ammonia and carbamate at a rate $10^{15}$ times higher than the uncatalyzed reaction, making it the most efficient enzyme known to date [1]. Carbamate then spontaneously evolves to produce another molecule of ammonia and carbon dioxide. Urease catalyzes this last step of organic nitrogen mineralization in bacteria, fungi, plants, algae and invertebrates [2-5]. The overall hydrolysis of the products generated by urease activity determines an increase in $\mathrm{pH}$ of the surrounding milieu, causing negative consequences in medical and agricultural settings [2-7]. This enzyme represents the main virulence factor for a large variety of ureolytic human pathogens such as Helicobacter pylori [8], Mycobacterium tuberculosis [9], Yersinia enterocolitica [10], Cryptococcus neoformans [11], and Proteus mirabilis [12]. Furthermore, ureolytic bacteria expressing urease are widespread in soils that are treated with urea, a nitrogen fertilizer used worldwide [13], and their activity contributes to a number of significant environmental and economic problems such as loss of nitrogen from soil and release of ammonia in the atmosphere, ammonia toxicity for plants, and seedlings damage [14]. In all these instances, a tight control of urease activity is required to counteract its deleterious effects. For this purpose, several classes of molecules have been proposed and tested, both in medicine and agriculture, as urease inhibitors [4, 15-18].

Knowledge about the structure of the nickel-containing active site cavity has been derived through studies on native ureases isolated from several sources [19-22], which revealed a conservation in the coordination environment around the two Ni(II) ions (Figure 1A).

Figure 1 here

On the basis of structural information obtained from the crystal structures of native Sporosarcina pasteurii (formerly known as Bacillus pasteurii) urease (SPU) $[18,20]$ and of its complexes with a 
range of other ligands [18, 20, 23-27], a general scheme of the catalytic mechanism of ureases was proposed $[1,5,20,28-31]$. In this mechanism, the nickel-bridging hydroxide acts as the nucleophilic group that attacks the urea molecule chelating the bimetallic nickel cluster using an oxygen atom and a nitrogen atom. An extended network of second shell hydrogen bonds appears to stabilize the substrate binding during the catalytic process. In addition, a flexible flap changes the active site channel from an open to a closed conformation (Figure 1B).

Sulfite has been extensively used as a preservative in solutions of jack bean (Canavalia ensiformis urease, JBU) [32, 33] and SPU [18, 20, 23-27, 34, 35]. The role of sulfite as a stabilizer of the urease activity has been interpreted in the past as due to the maintenance of the redox state of the conserved cysteine residue on the enzyme active site flap, which is essential for enzyme activity in its reduced thiol form (Figure 1B,C). Indeed, it is known that the thiol groups of cysteines can form oxygen derivatives such as sulfenic (Cys-SOH), sulfinic $\left(\mathrm{Cys}-\mathrm{SO}_{2} \mathrm{H}\right)$, and sulfonic (Cys$\mathrm{SO}_{3} \mathrm{H}$ ) functionalities [36], while stable sulfenic acids may be produced by mild oxidation of sterically hindered thiols [37]. In the case of the sulfenic functional group, the role of sulfite could be the intermediate formation of an enzymatically inactive S-sulfocysteine $\left(\mathrm{Cys}-\mathrm{S}_{-} \mathrm{SO}_{3}{ }^{-}\right)$, in turn undergoing hydrolysis to sulfate and back to Cys-SH:

$$
\mathrm{Cys}^{-}{ }^{\mathrm{S}} \mathrm{OH}+\mathrm{HSO}_{3}^{\ominus} \longrightarrow \mathrm{Cys}^{-}{ }^{-} \mathrm{SO}_{3}^{\ominus}+\mathrm{H}_{2} \mathrm{O} \longrightarrow \mathrm{Cys}^{-\mathrm{SH}}+\mathrm{HSO}_{4}^{\ominus}
$$

In addition, it has been shown that the enzymatic activity of JBU solutions, stored in the presence of $\beta$-mercaptoethanol (BME) but in contact with air oxygen, decreases [32] because of the formation of a mixed disulfide bond involving BME and the conserved active site flap Cys592 [22] This process is reverted by treatment of inactivated urease with sulfite [32] possibly through the reduction of this disulfide bond [38]:

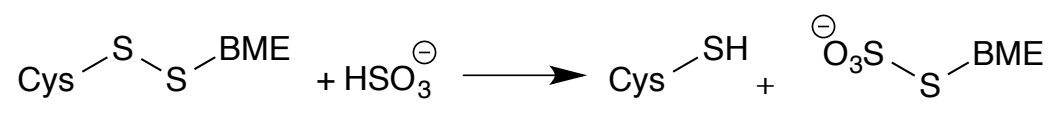

The opposite action of BME and sulfite on JBU was also suggested on the basis of an increase in the anodic electrophoretic mobility of native urease treated with sodium sulfite caused by an 
increased negative charge of the protein molecule; this process could be reversed by treatment with BME and was explained by the formation of S-sulfocysteines involving the several cysteine residues on the surface of JBU [39].

In addition to a protective action on the urease active site cysteine, sulfite has been reported to be an inhibitor of JBU, with a competitive inhibition mechanism deduced from the temperature dependence of the activation energy of the urea enzymatic hydrolysis as a function of sulfite concentration [40]. A pH-dependent kinetic study further suggested that the bisulfite mono-anion, and not the sulfite di-anion, is the actual inhibitor of JBU with inhibition constants in the millimolar range, and that this process does not entail an interaction of bisulfite with the sulfhydryl group of essential cysteines, but rather an addition to the active site, whose nature was still very obscure at the time [41]. These early reports were later supported by a study that indicated sulfite acting as a competitive inhibitor for JBU with an inhibition constant $\mathrm{K}_{\mathrm{i}}=2.23 \pm 0.45 \mathrm{mM}$ at $\mathrm{pH} 7.0$ [42]. This inhibition role of sulfite on urease was then proposed to involve a direct interaction with the $\mathrm{Ni}(\mathrm{II})$ ions in the active site on the basis of an apparent increase of the nickel affinity of JBU in the presence of this anion [38].

In this study, we report a molecular characterization of the inhibition SPU by sulfite. In particular, we describe and discuss the results of $\mathrm{pH}$-dependent enzyme kinetic measurements carried out using a calorimetry-based assay, indicating that sulfite acts as a competitive inhibitor of SPU. This conclusion is supported by the crystal structure of the SPU-sulfite complex at $1.65 \AA$ resolution, showing an unprecedented binding of the inhibitor to the active site $\mathrm{Ni}$ (II) ions through its three oxygen atoms.

\section{MATERIALS AND METHODS}

\subsection{Protein purification}

Sporosarcina pasteurii DSM 33 cells were obtained using a modification of a previously described procedure [18], and SPU was isolated in a pure form to a specific activity of about 2,500 
units per milligram using the following protocol. S. pasteurii cells, resuspended in a buffer containing $50 \mathrm{mM}$ phosphate $\mathrm{pH} 7.5,50 \mathrm{mM} \mathrm{Na} \mathrm{SO}_{3}, 1 \mathrm{mM}$ EDTA (buffer A), additionally containing $10 \mathrm{mM} \mathrm{MgCl}$ and $20 \mu \mathrm{g} / \mathrm{mL} \mathrm{DNAse} \mathrm{I,} \mathrm{were} \mathrm{disrupted} \mathrm{by} \mathrm{three} \mathrm{passages} \mathrm{through} \mathrm{a}$ French $^{\circledR}$ pressure cell press (SLM Aminco) at 20,000 psi. The soluble fraction was obtained by differential centrifugation, first at $30,000 \times \mathrm{g}$ for 30 minutes and then at 150,000 x $g$ for 2 hours, in order to remove cell debris and aggregates. The crude extract was dialyzed overnight against buffer A and then loaded onto a Q Sepharose XK 50/20 (GE Healthcare) anionic exchange column, previously equilibrated with the same buffer. A step gradient procedure was used to elute the protein with increasing ionic strength $(\mathrm{NaCl}$ in buffer $\mathrm{A}$ was used at concentrations of $150,350,450$

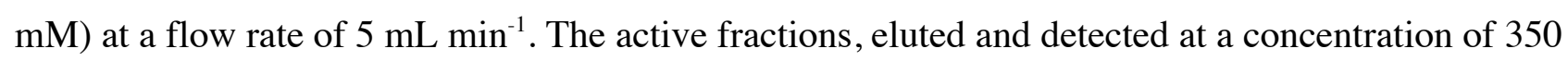
$\mathrm{mM} \mathrm{NaCl}$, were pooled and the ionic strength raised to $1 \mathrm{M}$ using $\left(\mathrm{NH}_{4}\right)_{2} \mathrm{SO}_{4}$. After centrifugation at $30,000 \times \mathrm{g}$ for 15 minutes to remove the precipitate, the solution was loaded onto a Phenyl Sepharose XK 26/20 (GE Healthcare) hydrophobic interaction column equilibrated with buffer A containing $1 \mathrm{M}\left(\mathrm{NH}_{4}\right)_{2} \mathrm{SO}_{4}$ and eluted with a linear gradient from $1 \mathrm{M}$ to $0 \mathrm{M}$ at a flow rate of $3 \mathrm{~mL}$ $\mathrm{min}^{-1}$. Urease, eluted with $400 \mathrm{mM}\left(\mathrm{NH}_{4}\right)_{2} \mathrm{SO}_{4}$, was concentrated using an Amicon ultrafiltration cell equipped with a membrane of 100,000 Dalton molecular weight cut-off. The resulting enzyme solution was loaded onto a Superdex 200 XK 16/60 (GE Healthcare) gel filtration column equilibrated with buffer $\mathrm{A}$, containing $150 \mathrm{mM} \mathrm{NaCl}$ in order to prevent non-specific interaction between the protein and the resin, and eluted at a flow rate of $1 \mathrm{~mL} \mathrm{~min}^{-1}$. The active fractions were pooled, and the ionic strength was decreased by dilution. The obtained solution was loaded onto a Mono Q HR 10/10 (Pharmacia) anionic exchange column, equilibrated with buffer A. Urease was eluted using a linear gradient of increasing ionic strength from 0 to $500 \mathrm{mM} \mathrm{NaCl}$ in buffer A. The active fractions were concentrated and further purified to homogeneity using a Superdex 200 10/300 GL (GE Healthcare) gel filtration column equilibrated with $20 \mathrm{mM} \quad N$-(2hydroxyethyl)piperazine- $N$ '-ethane-sulfonic acid sodium salt (HEPES), pH 7.5, containing $150 \mathrm{mM}$ $\begin{array}{llllllllll}\mathrm{NaCl} & \text { and } & 50 & \mathrm{mM} & \mathrm{Na}_{2} \mathrm{SO}_{3} & \text { (buffer } & \text { B) } & \text { at } & \text { a flow rate of } & 0.5\end{array}$ 
$\mathrm{mL} \mathrm{min}^{-1}$. Urease active fractions from the last step were concentrated to $11 \mathrm{mg} / \mathrm{mL}$ and stored in buffer $\mathrm{A}$ at $4{ }^{\circ} \mathrm{C}$.

\subsection{Kinetic studies}

Calorimetric experiments were carried out with a high-sensitivity VP-ITC (ITC: Isothermal Titration Calorimetry) micro-calorimeter (MicroCal LLC, Northampton, MA, USA), using a previously described enzymatic assay [18,43]. SPU was eluted through a Superdex 200 10/300 GL (GE Healthcare) size-exclusion chromatography column immediately before the measurements, using a $50 \mathrm{mM}$ HEPES pH 7.5 buffer, containing $50 \mathrm{mM} \mathrm{Na} 2 \mathrm{SO}_{3}, 2 \mathrm{mM}$ EDTA, and $150 \mathrm{mM}$ $\mathrm{NaCl}$, as eluent. The protein samples were then diluted to the concentrations used for the calorimetric experiments described below, using $50 \mathrm{mM}$ HEPES containing $2 \mathrm{mM}$ EDTA, at the $\mathrm{pH}$ value $(7.0,7.5$ or 8.0$)$ used in the experiment. The obtained enzyme solution was degassed and loaded into the ITC sample cell $(\mathrm{V}=1.4093 \mathrm{~mL})$. The ITC stirring injection syringe was filled with urea dissolved in $50 \mathrm{mM}$ HEPES containing $2 \mathrm{mM}$ EDTA to the concentrations used for the different experiments described below. The reference cell was filled with deionized water, and the temperature of the two cells was set and stabilized at 298 K. Stirring speed was $300 \mathrm{rpm}$, and thermal power was monitored every $2 \mathrm{~s}$ using high instrumental feedback. In order to determine the molar enthalpy of the reaction (M1 experiments), $30 \mathrm{nM}$ SPU and $20 \mathrm{mM}$ urea were used in cell and in syringe, respectively, and a single injection of $5 \mu \mathrm{L}$ urea was carried out, giving a final substrate concentration of $0.07 \mathrm{mM}$ in the sample cell. After the baseline returned to the original level, indicating that the consumption of the substrate was complete, a second and a third injection were performed, following the same procedure. Numerical integration of the area under the three single peaks was carried out using the native Origin package provided by the calorimeter manufacturer, and the average value thus obtained was used to calculate the molar enthalpy for urea hydrolysis. In order to derive the kinetic parameters $K_{M}$ and $\mathrm{k}_{c a t}$ (M2 experiments) $50 \mathrm{pM} \mathrm{SPU}$ and $0.5 \mathrm{M}$ urea were used in the cell and in the syringe, respectively. The enzyme was pre-incubated for $15 \mathrm{~min}$ at $25^{\circ} \mathrm{C}$ in $50 \mathrm{mM}$ HEPES, $2 \mathrm{mM}$ EDTA, at $\mathrm{pH} 7.0,7.5$ or 8.0 , and in the presence of a 
predefined amount of sulfite depending on the experiment (see below). Successive injections of 5 $\mu \mathrm{L}$ urea solution, containing sulfite at the same concentration of the enzyme solution, were carried out every $180 \mathrm{~s}$, a time necessary to allow the thermal trace to return to a steady-state level after each injection and, at the same time, maintain pseudo-first-order reaction conditions. The thermal power obtained from the baseline shift was averaged using the last $15 \mathrm{~s}$ prior to the subsequent injection to obtain an accurate measurement. The calculated thermal power for each injection was converted to reaction rate and corrected to take into account enzyme dilution. Control runs were carried out by injecting the urea solution into the buffer alone. All calorimetric experiments were carried out using a minimum required amount of sulfite $(20 \mu \mathrm{M})$, which was strictly necessary in order to keep the enzyme active during the course of the measurement. Indeed, analogous experiments performed in the total absence of sulfite indicated a progressive decrease of enzyme activity. Data were processed with the native Origin package. The reaction rates were obtained using a previously described protocol [18, 43].

The data analysis was based on the classic definitions of competitive, uncompetitive and mixed enzyme inhibition $[44,45]$. In the most general case, the rate of enzymatic reaction is given by:

$$
v=\frac{V_{\max } \cdot[\text { urea }]}{K_{m} \cdot\left(1+\frac{[I]}{K_{i c}}\right)+[\text { urea }] \cdot\left(1+\frac{[I]}{K_{i u}}\right)}
$$

In this expression, $V_{\max }=k_{\text {cat }}$ [urease] and $K_{m}$ are the maximum rate and the Michaelis constant, respectively, [I] is the molar concentration of the inhibitor, and $K_{i c}$ and $K_{i u}$ are the competitive and uncompetitive inhibition constants, respectively. The kinetic parameters were obtained from a fit of the experimental reaction rates obtained by calorimetry to the general inhibition Eq. 1, using nonlinear regression analysis implemented in the Origin package.

\subsection{Crystallization, data collection and structural determination}

Crystallization was performed at $293 \mathrm{~K}$ using the hanging-drop method. A solution of urease (11 $\mathrm{mg} \mathrm{mL} \mathrm{m}^{-1}, 3 \mu \mathrm{L}$ ) in $20 \mathrm{mM}$ HEPES, $\mathrm{pH} 7.5$, containing $150 \mathrm{mM} \mathrm{NaCl}$ and $50 \mathrm{mM} \mathrm{Na}_{2} \mathrm{SO}_{3}$, was 
diluted with $3 \mu \mathrm{L}$ of the precipitant solution (1.8-2.0 $\mathrm{M}$ ammonium sulfate in a $50 \mathrm{mM}$ sodium citrate buffer $\mathrm{pH} 6.3$ containing $50 \mathrm{mM} \mathrm{Na}_{2} \mathrm{SO}_{3}$ and 1-5\% dimethylsulfoxide, DMSO). The drop was equilibrated by vapor diffusion against $1 \mathrm{~mL}$ of the precipitant solution using a Hampton Research 24-well Linbro plate. Rice-shaped protein crystals appeared within 1-3 weeks and grew to a size of $0.1 \times 0.1 \times 0.3 \mathrm{~mm}^{3}$. Crystals were scooped up using cryoloops, transferred to a cryoprotectant solution containing $20 \%$ ethylene glycol, $2.4 \mathrm{M}$ ammonium sulfate, $50 \mathrm{mM}$ sodium citrate and $50 \mathrm{mM} \mathrm{Na}_{2} \mathrm{SO}_{3}$, and then flash-cooled and stored in liquid nitrogen.

Diffraction data were collected at $100 \mathrm{~K}$ using synchrotron radiation at the EMBL P13 beamline of the Petra III storage ring, c/o DESY Hamburg (Germany), equipped with a $\mathrm{Si}(111)$ crystal monochromator (FMB Oxford), a DECTRIS Pilatus 6M detector, and a MD2 goniometer (MAATEL-EMBL) with a horizontal spindle axis. Reflection data were collected from two crystals (1500 images for each crystal), by performing helical scans through the crystal to achieve higher resolution and minimize radiation damage. The data were processed using XDS [46] and AIMLESS [47]. The crystals are isomorphous with those of apo-SPU and other complexes of this enzyme (Table 1).

The model of SPU in complex with citrate (PDB code 4AC7, $1.50 \AA$ resolution) [27], devoid of water molecules and ligands, was used as a starting model for the rigid body refinement of the single $\alpha \beta \gamma$ protein trimer, carried out using Refmac [48, 49]. Manual model building was conducted using Coot $[50,51]$. The structure was isotropically refined, including the hydrogen atoms in the riding positions. The diffraction data and final refinement statistics are given in Table 1 . The structure was deposited in the Protein Data Bank under the accession code 5A6T. Crystallographic figures were created using Chimera [52] or CrystalMaker 8.7 (http://www .crystalmaker.com/ ).

Table 1 here 


\subsection{Theoretical calculations}

Density functional theory (DFT) computations were carried out using the program ORCA 3.0.3 [53] and the Becke three-parameter hybrid functional combined with Lee-Yang-Parr correlation functional (B3LYP/G) $[54,55]$ as defined in the Gaussian software [56]. All atoms were described by the Dunning correlation-consistent polarized triple zeta basis set with the inclusion of diffuse functions (aug-cc-pVTZ) [57]. Frequency computations were performed to determine the nature of the various critical points.

\section{RESULTS}

\subsection{Calorimetric analysis}

The inhibition of $S$. pasteurii urease by sulfite was investigated using isothermal titration calorimetry (ITC), a method that provides a universal approach to determining the kinetic behavior of enzymes by yielding, in a single experiment, a complete set of kinetic parameters for an enzymecatalyzed reaction [43, 58-61]. A very similar approach has been recently described for other metallo hydrolases [62].

The molar reaction enthalpy $(\Delta H)$ of the hydrolysis of urea by urease was determined using a socalled M1 experiment, in which a single injection of the substrate solution into a concentrated enzyme solution determined a decrease of the instrumental thermal power necessary to maintain the reference and the sample cell at a constant temperature, indicating an exothermic reaction. Complete consumption of the substrate occurred in the range $500-2000 \mathrm{~s}$, depending on the working $\mathrm{pH}$ in the $7.0-8.0$ range (Figure $2 \mathrm{~A}$ ). Two further injections of substrate into the reaction cell provided curves with identical profile, showing negligible inhibition by products (Figure 2A). The integration of the curves yielded $\Delta H=-11.3 \pm 0.2 \mathrm{kcal} \mathrm{mol}^{-1}$. A progressive increase of the reaction rate with increasing $\mathrm{pH}$ was observed in the $7.0-8.0$ range, consistent with the known $\mathrm{pH}$ dependence of the enzyme activity for SPU [63]. 
Figure 2 here

The so-called M2 experiments (Figure 2B) were performed using a diluted enzyme solution in the sample cell and carrying out multiple injections of a concentrated substrate solution, in the $\mathrm{pH}$ range 7.0 - 8.0. These experiments revealed an initial increase in thermal power due to the heat of substrate dilution, followed by a decrease required to maintain isothermal conditions for the exothermic reaction. The rate of heat generated by the enzyme is equivalent to the decrease in thermal power after each injection, steadily increasing as the substrate concentration increases. Analogous experiments carried out using $1.6 \mathrm{mM}$ sulfite (Figure 2B) showed a decrease of the reaction rate. Monitoring the latter as a function of substrate concentration and $\mathrm{pH}$ (in the range 7.0 - 8.0), as shown in Figure S1 (Supplementary Information), yielded a series of data that were fit to Eq. 1, resulting in the kinetic parameters reported in Table 2. The increase of $k_{c a t}$ as a function of pH in the explored range is in complete agreement with previous literature data indicating an optimum $\mathrm{pH}$ for SPU of ca. 7.7 [63]. The Michaelis-Menten constant, slightly smaller than the value of 17.3 $\mathrm{mM}$ reported in phosphate buffer $[34,63]$, is invariant with $\mathrm{pH}$. The parameters in Table 2 further show values of $K_{i c}$ « $K_{i u}$, indicative of a competitive mechanism of inhibition of urease by sulfite in the investigated $\mathrm{pH}$ range. This inhibition effect strongly decreases upon $\mathrm{pH}$ increase, becoming undetectable at $\mathrm{pH}$ 8.0.

Table 2 here

\subsection{Structural analysis}

The crystal structure of sulfite-inhibited SPU, showing the well-established architecture of this metallo-enzyme, closely matches that of the native protein (PDB code 4CEU, used here as reference for comparison because it has been refined to the highest resolution so far available, 1.58 
A) [18]. The global pairwise root mean square deviation (RMSD) per residue between C $\alpha$ atoms of the two structures is only $0.11,0.06$ and $0.05 \AA$ for the $\alpha, \beta$ and $\gamma$ subunits, respectively, and the overall RMSD is $0.10 \AA$. The analysis of the residue-averaged backbone B factors, as well as the $\phi$ and $\varphi$ protein backbone angles (Figure S2-S4), reveals two regions in the $\alpha$ subunit that feature a significantly larger mobility than the rest of the protein. Region A (residues 380-405) is located on a surface patch and involves a helix and a solvent-exposed loop. This region has been proposed [27] to participate in either the catalytic mechanism or the interaction with UreD, the accessory protein that, along with its partners UreF, UreG and UreE, forms the supercomplex that is necessary for the delivery of the two Ni(II) ions into the active site cavity and for the consequent urease activation [5, 64]. Region B (residues 305-350) corresponds to the flap, consisting of a helix-loop-helix motif, responsible for the modulation of the substrate access to the active site cavity (Figure 1B). The sulfite-bound SPU structure displays an "open” flap, as observed in the case of native urease [18, 20], as well as in all the other cases of SPU-inhibitor complex structures so far determined [18, 2327], except for urease inhibited by diamidophosphate (DAP), whose crystal structure presents the flap in the completely "closed" position [20]. Since DAP is generated in situ from the hydrolysis of phenylphosphorodiamidate, simulating the catalytic intermediate or transition state, the closed-flap conformation was proposed to stabilize the intermediate or transition state of the catalysis [20]. In the refined model (Figure 3A and Figure 4), the two Ni(II) ions are bridged by the carboxylate group of the carbamylated Lys220*, which is bound to $\mathrm{Ni}(1)$ by $\mathrm{O} \theta 1$ and to $\mathrm{Ni}(2)$ by $\mathrm{O} \theta 2$, allowing the two $\mathrm{Ni}$ (II) ions to be properly placed for the catalytic process. $\mathrm{Ni}(1)$ is further coordinated by

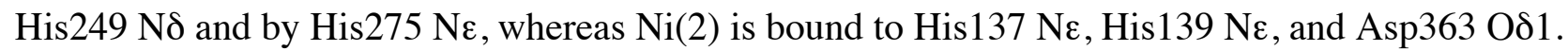

The unbiased electron density map calculated with Fourier coefficients $F_{o}-F_{c}$ and phases derived from the model of SPU in complex with citrate (PDB code 4AC7, $1.50 \AA$ resolution) [27], devoid of water molecules and ligands, displays an electron density in the volume around and between the $\mathrm{Ni}(\mathrm{II})$ ions that clearly indicates the existence of a trigonal pyramidal non-protein ligand bound to 
the two metal ions. (Figure 3B). This electron density is very different from what would be expected if four solvent-derived molecules were present in the active site (see, for example, the maps reported in [18]). Given the presence of sulfite in the crystallization solution, this moiety was modeled into the electron density and refined with full occupancy (Figure 4). In the refined model, the sulfite molecule is bound in a tridentate binding mode to the two Ni(II) ions in the active site, replacing the terminal and the bridging solvent molecules that were bound to $\mathrm{Ni}(1)$ and $\mathrm{Ni}(2)$ in the native form of the enzyme. This type of coordination is unprecedented both in protein and in small molecules structures. In this mode, sulfite binds the two Ni(II) ions at the active site using two oxygen atoms [ $\mathrm{Ni}(1)-\mathrm{O}(1)$ and $\mathrm{Ni}(2)-\mathrm{O}(2)$, respectively], placing its third oxygen atom, $\mathrm{O}(\mathrm{B})$, in the bridging position. The positions of the conserved amino acid residues, which are not involved in the $\mathrm{Ni}$ (II) binding but are known to be crucial in the catalytic mechanism (Ala170, His222, Glu223, Asp224, Gly280, His323, Ala366 and Met367), are largely conserved between the native and inhibited urease. This conservation of the structure of the active site residues is generally observed also in all other structures of SPU.

Figure 3 here

Figure 4 here

A comparison of the geometric parameters around the two Ni(II) ions in the active site of native and sulfite-bound urease, presented in Table S1, reveals that the structure is rigidly maintained.

The molecule of sulfite bound to urease is slightly asymmetric, with $\mathrm{S}-\mathrm{O}(1)=1.67 \AA$, $\mathrm{S}-\mathrm{O}(2)=$ $1.57 \AA$, and $\mathrm{S}-\mathrm{O}(\mathrm{B})=1.83 \AA$. Moreover, the sulfite molecule forms a series of hydrogen bonds with the residues that surround the active site cavity (Figure 4): $O(1)$ forms a hydrogen bond with His222 NE (at $2.65 \AA$ ) that is protonated and acts as a hydrogen-bond donor, as deduced from the

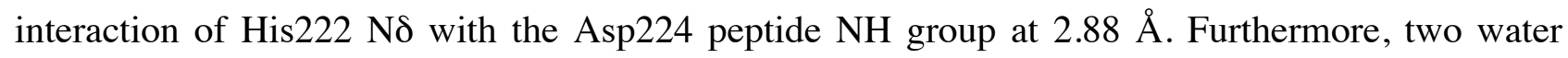


molecules are H-bonded to $\mathrm{O}(1)$ at $3.19 \AA$ and $3.21 \AA$. The sulfite oxygen $\mathrm{O}(2)$, bound to $\mathrm{Ni}(2)$, is placed at $2.78 \AA$ from the carbonyl backbone Ala170 O, suggesting a possible H-bond in which the sulfite $\mathrm{O}(2)$ could be protonated. Finally, the bridging sulfite $\mathrm{O}(\mathrm{B})$ is placed at $2.48 \AA$ from Asp363

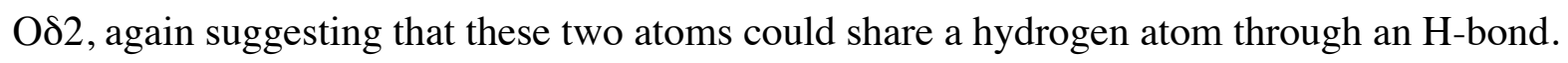

\section{DISCUSSION}

The present study focuses on the biochemical and structural features of the interaction of the urease from S. pasteurii with sulfite, a known urease inhibitor [40-42] as well as a stabilizer of urease activity [18, 20, 23-27, 32-35]. Enzymatic measurements of sulfite inhibition of urease were performed on SPU using a calorimetric method, and the results were integrated with the analysis of high-resolution crystallographic data of sulfite-inhibited urease. The calorimetric data show that sulfite inhibits the activity of SPU with a $\mathrm{pH}$-dependent competitive mechanism in the 7.0-8.0 range. These results, obtained on SPU, are in agreement with early data on JBU [41], and suggest a common mechanism of urease inhibition by sulfite among ureases from different sources. Among the several classes of urease inhibitors known to date [4], the competitive inhibition constant determined for sulfite at $\mathrm{pH} 7.0(0.19 \mathrm{mM})$ compares well with the analogous value reported for boric acid $(0.08-0.35 \mathrm{mM})$ and $\operatorname{BME}(0.72 \mathrm{mM})$, while it performs better then urea analogues $(1.45-980 \mathrm{mM})$, phosphate $(19 \mathrm{mM})$, and bismuth derivatives $(1.74-1.84 \mathrm{mM})$.

The competitive nature of the inhibition indicates that sulfite, in one of its protonated forms, competes with the substrate urea for the active site $\mathrm{Ni}(\mathrm{II})$ ions. In particular, the inhibition decreases almost an order of magnitude by increasing the $\mathrm{pH}$ from 7.0 to 7.5 , and becomes negligible upon further increase of the $\mathrm{pH}$ up to 8 : this observation excludes that the inhibitor takes the di-anionic $\mathrm{SO}_{3}{ }^{2-}$ form, but does not in principle distinguish between the mono-anionic and the neutral nondissociated form of sulfite $\left(\mathrm{pK}_{\mathrm{a} 1}=1.85\right.$ and $\mathrm{pK}_{\mathrm{a} 2}=7.20$ [65]) because of the limited $\mathrm{pH}$ interval that could be explored without causing enzyme degradation at low $\mathrm{pH}$. Even though the crystallization 
buffer $\mathrm{pH}=6.3$ would support the presence of the mono-anionic inhibitor as the main form of sulfite in solution, the presence of the neutral form of the inhibitor in the urease active site cannot be excluded on the sole basis of these criteria.

Consistent with these kinetic observations, high resolution crystallographic data demonstrate that the inhibitor binds in the active site displacing three solvent-derived $\mathrm{Ni}(\mathrm{II})$-bound molecules and replacing these position with its three oxygen atoms, blocking access of urea to the key metal ions. This tripodal coordination mode of sulfite has never been observed either in proteins or in small molecules complexes, and represents an exciting twist in the chemistry of $\mathrm{Ni}(\mathrm{II})$ in urease. Binuclear metallo-hydrolases are not new to this kind of tripodal ligand coordination mode: sulfate binds the $\mathrm{Mn}-\mathrm{Mn}$ center of bacteriophage $\lambda$ protein phosphatase [66], while phosphate binds the FeMn center in purple acid phosphatase from sweet potato [67] and Lupinus luteus [68], as well as the di-nickel center of urease [25], using three out of the four oxygen atoms of the anion.

The structure of the bisulfite ion has actually been the subject of some debate: the $\mathrm{HSO}_{3}{ }^{-}$ion could adopt either a $\mathrm{C}_{3 \mathrm{v}}$ structure $\left(\mathrm{HSO}_{3}{ }^{-}\right)$, in which the $\mathrm{H}$ atom is bound to sulfur, or a $\mathrm{C}_{1}$ structure $\left[\mathrm{SO}_{2}(\mathrm{OH})\right]^{-}$, in which a $\mathrm{OH}$ group is bound to $\mathrm{S}$. Previous experimental data and quantum mechanical calculations showed that, in the first case, the three S-O bonds should be identical (bond distance ca. $1.47 \AA$, bond order $=5 / 3$ ), while in the second case the S-OH bond would be longer (ca. 1.75-1.78 $\AA$, bond order = 1) than the other two S-O bonds (ca. 1.49-1.50 $\AA$, bond order = 3/2) [69]. In aqueous solution the $C_{1}$ isomer is more energetically stable than the $C_{3 v}$ isomer by only 4.9 $\mathrm{kcal} \mathrm{mol}^{-1}[70]$, suggesting that the adopted structure would depend on the chemical environment [69]. The sulfite ion $\mathrm{SO}_{3}{ }^{2-}$, on the other hand, can adopt only $\mathrm{C}_{3 \mathrm{v}}$ geometry with identical S-O bond distances of $1.53 \AA$ in solution (bond order $=4 / 3$ ) [71]. In order to distinguish between the different protonated forms of sulfite, we carried out quantum mechanical calculations, and compared the computed structural parameters with those determined in the crystal structure of sulfite-inhibited SPU (Tables 3 and S2). 
Table 3 here

Our calculations largely confirm these previously reported values, additionally indicating that the neutral form $\mathrm{H}_{2} \mathrm{SO}_{3}$ would possess one short and two long $\mathrm{S}-\mathrm{O}$ distances. The asymmetric collection of S-O bond distances found in the crystal structure of SPU bound to this inhibitor (1.57 $\AA$, $1.67 \AA$, and $1.83 \AA$ for $\mathrm{S}-\mathrm{O}(1), \mathrm{S}-\mathrm{O}(2)$ and $\mathrm{S}-\mathrm{O}(\mathrm{B})$ respectively), in a short-short-long distribution (Table 3), are neither compatible with the $\mathrm{SO}_{3}{ }^{2-}$ ion (as also suggested by the previous considerations on the crystallization $\mathrm{pH}$ vs. the $\mathrm{pK}_{\mathrm{a}}$ of $\mathrm{HSO}_{3}{ }^{-}$), nor with the $\mathrm{C}_{3 \mathrm{v}}$ isomer of this anion, nor with the neutral form of the inhibitor, supporting instead the presence of the $\left[\mathrm{SO}_{2}(\mathrm{OH})\right]^{-}$monoanionic form of sulfite bound to the active site $\mathrm{Ni}(\mathrm{II})$ ions. In particular, the long $\mathrm{S}-\mathrm{O}(\mathrm{B})$ distance

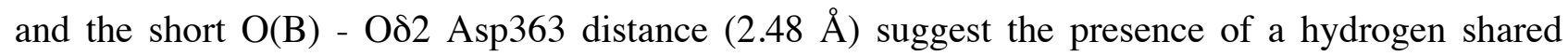
between these two $\mathrm{O}$ atoms. On the other hand, the longer distance involving S-O(1) vs. S-O(2) could be determined by the presence of the hydrogen-bonding donor His $222 \mathrm{N \varepsilon H}$ in the close vicinity of $\mathrm{O}(1)$ (at $2.65 \AA$ ) that could have an effect of decreasing the negative charge on $\mathrm{O}(1)$; this consideration would also justify the longer distance $(2.20 \AA)$ between $\mathrm{Ni}(1)$ and $\mathrm{O}(1)$ as compared to the distance $(2.10 \AA$ ) between $\mathrm{Ni}(2)$ and $\mathrm{O}(2)$. In general, the S-O distances found in the crystal structure of the complex are ca. 0.1-0.2 $\AA$ longer than those expected for the bisulfite $\mathrm{C}_{1}$ isomer in aqueous solution: this could be due to the presence of the two $\mathrm{Ni}$ (II) ions bound to the anion. Indeed, a similar effect has been observed in the case of the structure of human carbonic anhydrase II complexed with bisulfite (PDB code 2CBD) [72]: this structure, solved at $1.67 \AA$ resolution, together with an older structure of the same enzyme solved at $2.0 \AA$ resolution (PDB code 5CAC) [73], is the only case that shows a sulfite ion bound to a metal ion in a protein, namely $\mathrm{Zn}$ (II), in a terminal mode, using a presumably protonated $\mathrm{O}$ atom, as manifested by the network of H-bonds around it [72]. In this case, the length of the $\mathrm{S}-\mathrm{O}(\mathrm{H})$ bond involving the oxygen atom bound to $\mathrm{Zn}$ (II) is $1.82 \AA$, a value essentially identical to the $\mathrm{S}-\mathrm{O}(\mathrm{B})$ distance in the SPU-sulfite complex, 
while the other two S-O bond lengths, involving O atoms not bound to other metal ions, are 1.461.47 $\AA$, consistent with the distances observed for the $\mathrm{C}_{1}$ isomer of $\mathrm{HSO}_{3}^{-}$. All these considerations further support the presence of the mono-anionic $\mathrm{C} 1$ form of sulfite. However, the possibility of an additional H-bond formed between sulfite $\mathrm{O}(2)$ and the carbonyl backbone Ala170 O does not fully rule out the presence of the neutral, fully protonated, sulfurous acid.

The presence of sulfite bound to metal ions in proteins is not unique: a research performed using the MetalPDB search server (http://metalweb.cerm.unifi.it) [74] reveals that, in addition to the above mentioned carbonic anhydrase II, sulfite is detected bound to the heme Fe atom in the active site of sulfite and nitrate reductases. In all those instances, however, sulfite is bound to the metal ion through the $\mathrm{S}$ atom and not using the whole set of $\mathrm{O}$ atoms as found in the active site of sulfiteinhibited S. pasteuri urease. A search of the Cambridge Crystallographic Database (http://www.ccdc.cam.ac.uk), containing small molecules, gave no hits for this coordination mode of sulfite, further reinforcing the novelty of this coordination mode. In this context, is worth mentioning that the effect of sulfite on a newly discovered Ni-containing enzyme, lactate racemase (Lar), has been recently reported [75]. This enzyme contains an organometallic nickel-containing prosthetic group, and sulfite was shown to act as a potent mixed inhibitor as well as being able to stabilize Lar activity and delay Ni loss; however, the molecular details of these effects have not been clarified [75].

\section{CONCLUSIONS}

The kinetics of inhibition of S. pasteurii urease with sulfite, determined using an enzyme assay based on microcalorimetry, indicate that this molecule acts as a competitive inhibitor. This result is confirmed by the structure of the urease-sulfite complex, which shows the inhibitor bound to the active site $\mathrm{Ni}(\mathrm{II})$ ions and blocking access to urea, the natural substrate for this enzyme. The structure of the nickel-bound sulfite described in the present article is unprecedented and expands the coordination chemistry of this inorganic molecule to include a tridentate mode. The latter might 
inspire model inorganic chemists towards the synthesis of analogous complexes and investigate their chemical and reactivity properties. At the same time, the results illustrated here could stimulate research towards urease inhibitors based on oxidized sulfur functional groups, demonstrated here to be able to act as efficient modulators of enzyme activity.

\section{Acknowledgements}

Research partially supported by Specialty Fertilizer Products (Leawood, KS, USA) and by CIRMMP (Consorzio Interuniversitario di Risonanze Magnetiche di Metallo-Proteine. We are indebted to Dr Antonio Vara for his assistance in S. pasteurii cell growth. LM is a recipient of a Ph.D. fellowship from the University of Bologna. FM is a research assistant supported by the University of Bologna through a FARB Program (Finanziamenti dell'Alma Mater Studiorum alla Ricerca di Base). We thank the European Molecular Biology Laboratory (EMBL, Petra III, c/o DESY, Hamburg, Germany) for the available beam time. X-ray diffraction data were collected under the beam time award number MX-333. 


\section{REFERENCES}

[1] M. J. Maroney, S. Ciurli, Chem. Rev. 114 (2014) 4206-4228.

[2] H. L. Mobley, R. P. Hausinger, Microbiol. Rev. 53 (1989) 85-108.

[3] P. A. Karplus, M. A. Pearson, R. P. Hausinger, Acc. Chem. Res. 30 (1997) 330-337.

[4] B. Krajewska, J. Mol. Catal. B - Enzym. 59 (2009) 9-21.

[5] B. Zambelli, F. Musiani, S. Benini, S. Ciurli, Acc. Chem. Res. 44 (2011) 520-530.

[6] B. P. Callahan, Y. Yuan, R. Wolfenden, J. Am. Chem. Soc. 127 (2005) 10828-10829.

[7] C. Follmer, Phytochemistry 69 (2008) 18-28.

[8] C. Montecucco, R. Rappuoli, Nat. Rev. Mol. Cell. Biol. 2 (2001) 457-466.

[9] W. Lin, V. Mathys, E. L. Ang, V. H. Koh, J. M. Martinez Gomez, M. L. Ang, S. Z. Zainul Rahim, M. P. Tan, K. Pethe, S. Alonso, Infect. Immun. 80 (2012) 2771-2779.

[10] G. M. Young, D. Amid, V. L. Miller, J. Bacteriol. 178 (1996) 6487-6495.

[11] G. M. Cox, J. Mukherjee, G. T. Cole, A. Casadevall, J. R. Perfect, Infect. Immun. 68 (2000) 443-448.

[12] B. D. Jones, C. V. Lockatell, D. E. Johnson, J. W. Warren, H. L. Mobley, Infect. Immun. 58 (1990) 1120-1123.

[13] P. J. E. H. R. D. Stangel, American Society of Agronomy, Crop Science Society of America, Soil Science Society of America, 1984, pp. 23-54.

[14] J. M. M. Bremner, R. L., in: R.G. Burns (Ed.), Soil Enzymes, 1978.

[15] B. Krajewska, W. Zaborska, M. Leszko, J. Mol. Catal. B - Enzym. 14 (2001) 101-109.

[16] W. Zaborska, B. Krajewska, Z. Olech, J. Enz. Inhib. Med. Chem. 19 (2004) 65-69.

[17] P. Kosikowska, L. Berlicki, Expert Opin. Ther. Pat. 21 (2011) 945-957.

[18] S. Benini, M. Cianci, L. Mazzei, S. Ciurli, J. Biol. Inorg. Chem. 19 (2014) 1243-1261.

[19] E. Jabri, M. B. Carr, R. P. Hausinger, P. A. Karplus, Science 268 (1995) 998-1004.

[20] S. Benini, W. R. Rypniewski, K. S. Wilson, S. Miletti, S. Ciurli, S. Mangani, Structure 7 (1999) 205-216. 
[21] N. C. Ha, S. T. Oh, J. Y. Sung, K. A. Cha, M. H. Lee, B. H. Oh, Nat. Struct. Biol. 8 (2001) 505-509.

[22] A. Balasubramanian, K. Ponnuraj, J. Mol. Biol. 400 (2010) 274-283.

[23] S. Benini, W. R. Rypniewski, K. S. Wilson, S. Ciurli, S. Mangani, J. Biol. Inorg. Chem. 3 (1998) 268-273.

[24] S. Benini, W. R. Rypniewski, K. S. Wilson, S. Miletti, S. Ciurli, S. Mangani, J. Biol. Inorg. Chem. 5 (2000) 110-118.

[25] S. Benini, W. R. Rypniewski, K. S. Wilson, S. Ciurli, S. Mangani, J. Biol. Inorg. Chem. 6 (2001) 778-790.

[26] S. Benini, W. R. Rypniewski, K. S. Wilson, S. Mangani, S. Ciurli, J. Am. Chem. Soc. 126 (2004) 3714-3715.

[27] S. Benini, P. Kosikowska, M. Cianci, L. Mazzei, A. G. Vara, L. Berlicki, S. Ciurli, J. Biol. Inorg. Chem. 18 (2013) 391-399.

[28] S. Ciurli, S. Benini, W. R. Rypniewski, K. S. Wilson, S. Miletti, S. Mangani, Coord. Chem. Rev. 190-192 (1999) 331-355.

[29] F. Musiani, E. Arnofi, R. Casadio, S. Ciurli, J. Biol. Inorg. Chem. 6 (2001) 300-314.

[30] S. Ciurli, Nickel and Its Surprising Impact in Nature, John Wiley \& Sons, Ltd, 2007, pp. 241277.

[31] S. Benini, F. Musiani, S. Ciurli, in: R. Kretsinger, V. Uversky, E. Permyakov (Eds.), Encyclopedia of Metalloproteins, Springer New York, 2013, pp. 2287-2292.

[32] P. W. Riddles, R. K. Andrews, R. L. Blakely, B. Zerner, BBA - Protein Struct. M. 743 (1983) 115-120.

[33] B. Zerner, Bioorg. Chem. 19 (1991) 116-131.

[34] S. Benini, Gessa, C., Ciurli, S., Soil Biol. Biochem. 28 (1996) 819-821.

[35] S. Ciurli, C. Marzadori, S. Benini, S. Deiana, C. Gessa, Soil Biol. Biochem. 28 (1996) 811817. 
[36] K. G. Reddie, K. S. Carroll, Curr. Opin. Chem. Biol. 12 (2008) 746-754.

[37] W. S. Allison, Acc. Chem. Res. 9 (1976) 293-299.

[38] G. J. King, B. Zerner, Inorg. Chim. Acta 255 (1997) 381-388.

[39] J. J. Martín de Llano, J. G. Gavilanes, Electrophoresis 13 (1992) 300-304.

[40] G. B. Kistiakowsky, R. Lumry, J. Am. Chem. Soc. 71 (1949) 2006-2013.

[41] J. F. Ambrose, G. B. Kistiakowsky, A. G. Kridl, J. Am. Chem. Soc. 72 (1950) 317-321.

[42] R. K. Andrews, School of Molecular and Microbial Sciences, vol. Ph.D., University of Queensland, Brisbane, Australia, 1986.

[43] L. Mazzei, S. Ciurli, B. Zambelli, J. Vis. Exp. (2014) e51487.

[44] I. H. Segel, Enzyme Kinetics: Behavior and Analysis of Rapid Equilibrium and Steady-State Enzyme Systems, Wiley-Interscience, 1993.

[45] A. Cornish-Bowden, Perspect. Science 1 (2014) 74-87.

[46] W. Kabsch, Acta Crystallogr. D Biol. Crystallogr. 66 (2010) 125-132.

[47] P. Evans, Acta Crystallogr. D Biol. Crystallogr. 62 (2006) 72-82.

[48] G. N. Murshudov, A. A. Vagin, E. J. Dodson, Acta Crystallogr. D Biol. Crystallogr. 53 (1997) 240-255.

[49] G. N. Murshudov, A. A. Vagin, A. Lebedev, K. S. Wilson, E. J. Dodson, Acta Crystallogr. D Biol. Crystallogr. 55 (1999) 247-255.

[50] P. Emsley, K. Cowtan, Acta Crystallogr. D Biol. Crystallogr. 60 (2004) 2126-2132.

[51] P. Emsley, B. Lohkamp, W. G. Scott, K. Cowtan, Acta Crystallogr. D Biol. Crystallogr. 66 (2010) 486-501.

[52] E. F. Pettersen, T. D. Goddard, C. C. Huang, G. S. Couch, D. M. Greenblatt, E. C. Meng, T. E. Ferrin, J. Comput. Chem. 25 (2004) 1605-1612.

[53] F. Neese, Wiley Interdisciplinary Reviews: Computational Molecular Science 2 (2012) 73-78.

[54] A. D. Becke, J. Chem. Phys. 98 (1993) 1372-1377.

[55] C. Lee, W. Yang, R. G. Parr, Phys. Rev. B 37 (1988) 785-789. 
[56] M. J. Frisch, G. W. Trucks, H. B. Schlegel, G. E. Scuseria, M. A. Robb, J. R. Cheeseman, G. Scalmani, V. Barone, B. Mennucci, G. A. Petersson, H. Nakatsuji, M. Caricato, X. Li, H. P. Hratchian, A. F. Izmaylov, J. Bloino, G. Zheng, J. L. Sonnenberg, M. Hada, M. Ehara, K. Toyota, R. Fukuda, J. Hasegawa, M. Ishida, T. Nakajima, Y. Honda, O. Kitao, H. Nakai, T. Vreven, J. A. Montgomery Jr., J. E. Peralta, F. Ogliaro, M. J. Bearpark, J. Heyd, E. N. Brothers, K. N. Kudin, V. N. Staroverov, R. Kobayashi, J. Normand, K. Raghavachari, A. P. Rendell, J. C. Burant, S. S. Iyengar, J. Tomasi, M. Cossi, N. Rega, N. J. Millam, M. Klene, J. E. Knox, J. B. Cross, V. Bakken, C. Adamo, J. Jaramillo, R. Gomperts, R. E. Stratmann, O. Yazyev, A. J. Austin, R. Cammi, C. Pomelli, J. W. Ochterski, R. L. Martin, K. Morokuma, V. G. Zakrzewski, G. A. Voth, P. Salvador, J. J. Dannenberg, S. Dapprich, A. D. Daniels, Ö. Farkas, J. B. Foresman, J. V. Ortiz, J. Cioslowski, D. J. Fox, Gaussian, Inc., Wallingford, CT, USA, 2009.

[57] T. H. Dunning, J. Chem. Phys. 90 (1989) 1007-1023.

[58] C. Spink, I. Wadso, Methods Biochem. Anal. 23 (1976) 1-159.

[59] B. A. Williams, E. J. Toone, J. Org. Chem. 58 (1993) 3507-3510.

[60] M. J. Todd, J. Gomez, Anal. Biochem. 296 (2001) 179-187.

[61] M. W. Freyer, E. A. Lewis, Methods Cell Biol. (2008) 79-113.

[62] M. M. Pedroso, F. Ely, T. Lonhienne, L. R. Gahan, D. L. Ollis, L. W. Guddat, G. Schenk, J. Biol. Inorg. Chem. 19 (2014) 389-398.

[63] S. Ciurli, C. Marzadori, S. Benini, S. Deiana, C. Gessa, Soil Biol. Biochem. 28 (1996) 811817.

[64] S. Quiroz-Valenzuela, S. C. Sukuru, R. P. Hausinger, L. A. Kuhn, W. T. Heller, Arch. Biochem. Biophys. 480 (2008) 51-57.

[65] D. D. Perrin, Ionisation Constants of Inorganic Acids and Bases in Aqueous Solution, Pergamon, Oxford, 1982.

[66] W. C. Voegtli, D. J. White, N. J. Reiter, F. Rusnak, A. C. Rosenzweig, Biochemistry 39 (2000) 15365-15374. 
[67] G. Schenk, L. R. Gahan, L. E. Carrington, N. Mitic, M. Valizadeh, S. E. Hamilton, J. de Jersey, L. W. Guddat, Proc. Natl. Acad. Sci. U.S.A. 102 (2005) 273-278.

[68] S. V. Antonyuk, M. Olczak, T. Olczak, J. Ciuraszkiewicz, R. W. Strange, IUCr J. 1 (2014) 101-109.

[69] M. A. Vincent, I. J. Palmer, I. H. Hillier, J. Mol. Struct. - Theochem. 394 (1997) 1-9.

[70] D. A. Horner, R. E. Connick, Inorg. Chem. 25 (1986) 2414-2417.

[71] L. Eklund, T. S. Hofer, A. B. Pribil, B. M. Rode, I. Persson, Dalton Trans. 41 (2012) 52095216.

[72] K. Håkansson, M. Carlsson, L. A. Svensson, A. Liljas, J. Mol. Biol. 227 (1992) 1192-1204.

[73] A. E. Eriksson, T. A. Jones, A. Liljas, Proteins 4 (1988) 274-282.

[74] C. Andreini, G. Cavallaro, S. Lorenzini, A. Rosato, Nucl. Acids Res. 41 (2012) D312-D319.

[75] B. Desguin, T. Zhang, P. Soumillion, P. Hols, J. Hu, R. P. Hausinger, Science 349 (2015) 6669.

[76] M. S. Weiss, J. Appl. Crystallogr. 34 (2001) 130-135.

[77] D. W. J. Cruickshank, Acta Crystallogr. D Biol. Crystallogr. 55 (1999) 583-601.

[78] M. D. Winn, C. C. Ballard, K. D. Cowtan, E. J. Dodson, P. Emsley, P. R. Evans, R. M.

Keegan, E. B. Krissinel, A. G. W. Leslie, A. McCoy, S. J. McNicholas, G. N. Murshudov, N. S.

Pannu, E. A. Potterton, H. R. Powell, R. J. Read, A. Vagin, K. S. Wilson, Acta Crystallogr. D Biol.

Crystallogr., vol. 67, 2011, pp. 235-242. 
Table 1. X-ray diffraction data collection and refinement statistics for sulfite-bound Sporosarcina pasteurii urease (PDB code 5A6T)

\begin{tabular}{|c|c|}
\hline Data collection & \\
\hline Wavelength $(\AA)$ & 1.033 \\
\hline Crystal-to-Detector distance (mm) & 271.8 \\
\hline Oscillation angle (degrees) & 0.075 \\
\hline Number of images & 3000 \\
\hline Space group & $\mathrm{P} 6_{3} 22$ \\
\hline Unit cell $(a, b, c, \AA)$ & $131.24,131.24,188.88$ \\
\hline Resolution range $(\AA)^{1}$ & $97.46-1.65(1.68-1.65)$ \\
\hline Total number of reflections ${ }^{1}$ & $2478074(69467)$ \\
\hline Unique reflections $^{1}$ & $115020(5576)$ \\
\hline Multiplicity $^{1}$ & $21.5(12.5)$ \\
\hline Completeness $^{1}(\%)$ & $99.8(99.2)$ \\
\hline $\mathrm{R}_{\mathrm{sym}} 1,2(\%)$ & $0.102(0.471)$ \\
\hline $\mathrm{R}_{\text {pim }} 1,3(\%)$ & $0.030(0.199)$ \\
\hline Mean I half-set correlation CC(1/2) & 0.969 \\
\hline Mean $I / \sigma(I)^{1}$ & $29.4(5.7)$ \\
\hline \multicolumn{2}{|l|}{ Refinement statistics } \\
\hline Number of monomers in the asymmetric unit & 3 \\
\hline $\mathrm{R}_{\text {factor }}^{4}(\%)$ & 12.87 \\
\hline $\mathrm{R}_{\text {free }} 4(\%)$ & 15.25 \\
\hline Cruickshank's DPI for coordinate error ${ }^{5}$ based on $\mathrm{R}_{\text {factor }}(\AA)$ & 0.063 \\
\hline Wilson plot B-factor $\left(\AA^{2}\right)$ & 12.9 \\
\hline Average all atom B-factor ${ }^{6}\left(\AA^{2}\right)$ & 19.155 \\
\hline $\mathrm{B}$-factor of $\mathrm{Ni}$ atoms & Ni1: $18.5 ; \mathrm{Ni2}: 16.1$ \\
\hline B-factor of sulfite atoms & $\mathrm{S}: 25.1, \mathrm{O} 1: 23.5 ; \mathrm{O} 1: 28.2 ; \mathrm{O} 1: 22.1$ \\
\hline RMS (bonds) ${ }^{4}$ & 0.022 \\
\hline RMS (angles) ${ }^{4}$ & 2.067 \\
\hline Total number of atoms ${ }^{3}$ & 6864 \\
\hline Total number of water molecules & 636 \\
\hline Solvent content $(\%)$ & 55.23 \\
\hline Matthews Coefficient $\left(\AA^{3} / \mathrm{Da}\right)$ & 2.75 \\
\hline \multicolumn{2}{|l|}{ Ramachandran plot $^{7}$} \\
\hline Most favored region $(\%)$ & 90.7 \\
\hline Additionally allowed region (\%) & 8.4 \\
\hline Generously allowed region (\%) & 0.8 \\
\hline Disallowed region $(\%)$ & 0.2 \\
\hline
\end{tabular}

${ }^{1}$ highest resolution bin in parentheses; ${ }^{2} \mathrm{R}_{\text {sym }}=\sum_{\mathrm{hkl}} \sum_{\mathrm{j}}\left|\mathrm{I}_{\mathrm{j}}-\langle\mathrm{I}\rangle\right| / \sum_{\mathrm{hkl}} \sum_{\mathrm{j}} \mathrm{I}_{\mathrm{j}}$, where I is the intensity of a reflection, and $\langle\mathrm{I}\rangle$ is the mean intensity of all symmetry related reflections $\mathrm{j} ;{ }^{3} \mathrm{R}_{\text {p.i.m. }}=\sum_{\mathrm{hkl}}\{[1 / \mathrm{N}-$ 1)] $\left.\sum_{\mathrm{j}}\left|\mathrm{I}_{\mathrm{j}}-\langle\mathrm{I}\rangle\right|\right\}^{1 / 2} / \sum_{\mathrm{hkl}} \sum_{\mathrm{j}} \mathrm{I}_{\mathrm{j}}$, where I is the intensity of a reflection, and $\langle\mathrm{I}\rangle$ is the mean intensity of all symmetry related reflections $\mathrm{j}$, and $\mathrm{N}$ is the multiplicity [76]; ${ }^{4}$ taken from REFMAC [48, 49]; $\mathrm{R}_{\text {free }}$ is calculated using $5 \%$ of the total reflections that were randomly selected and excluded from refinement; ${ }^{5} \mathrm{DPI}=R_{\text {factor }} \cdot D_{\text {max }} \cdot \operatorname{compl} l^{-1 / 3} \sqrt{\frac{N_{\text {atoms }}}{\left(N_{\text {refl }}-N_{\text {params }}\right)}}$, where $N_{\text {atoms }}$ is the number of the atoms included in the refinement, $N_{\text {refl }}$ is the number of the reflections included in the refinement, $D_{\max }$ is the maximum resolution of reflections included in the refinement, compl is the completeness of the observed data, and for isotropic refinement, $N_{\text {params }} \approx 4 N_{\text {atoms }}$ [77]; ${ }^{6}$ taken from BAVERAGE [78]; ${ }^{7}$ taken from PROCHECK [78]. 
Table 2 Kinetic parameters for the inhibition of SPU with sulfite.

\begin{tabular}{rrrcc}
\hline $\mathbf{p H}$ & $\boldsymbol{k}_{\text {cat }}\left(\mathbf{s}^{-\mathbf{1}}\right)$ & $\boldsymbol{K}_{\boldsymbol{M}}(\mathbf{m M})$ & $\boldsymbol{K}_{\text {ic }}(\mathbf{m M})$ & $\boldsymbol{K}_{\text {iu }}(\mathbf{m M})$ \\
\hline 7.0 & $7953 \pm 36$ & $10.3 \pm 0.1$ & $0.19 \pm 0.03$ & $» 1$ \\
7.5 & $11631 \pm 70$ & $12.0 \pm 0.2$ & $1.17 \pm 0.02$ & $» 1$ \\
8.0 & $9939 \pm 49$ & $11.7 \pm 0.2$ & - & - \\
\hline
\end{tabular}


Table 3. B3LYP/G aug-cc-pVTZ distances $(\AA)$ of sulfurous acid, bisulfite ion in the $\mathrm{C}_{1}$ and in the $\mathrm{C}_{3 \mathrm{v}}$ forms, and sulfite ion compared with the distances found in the sulfite inhibited SPU crystal structure.

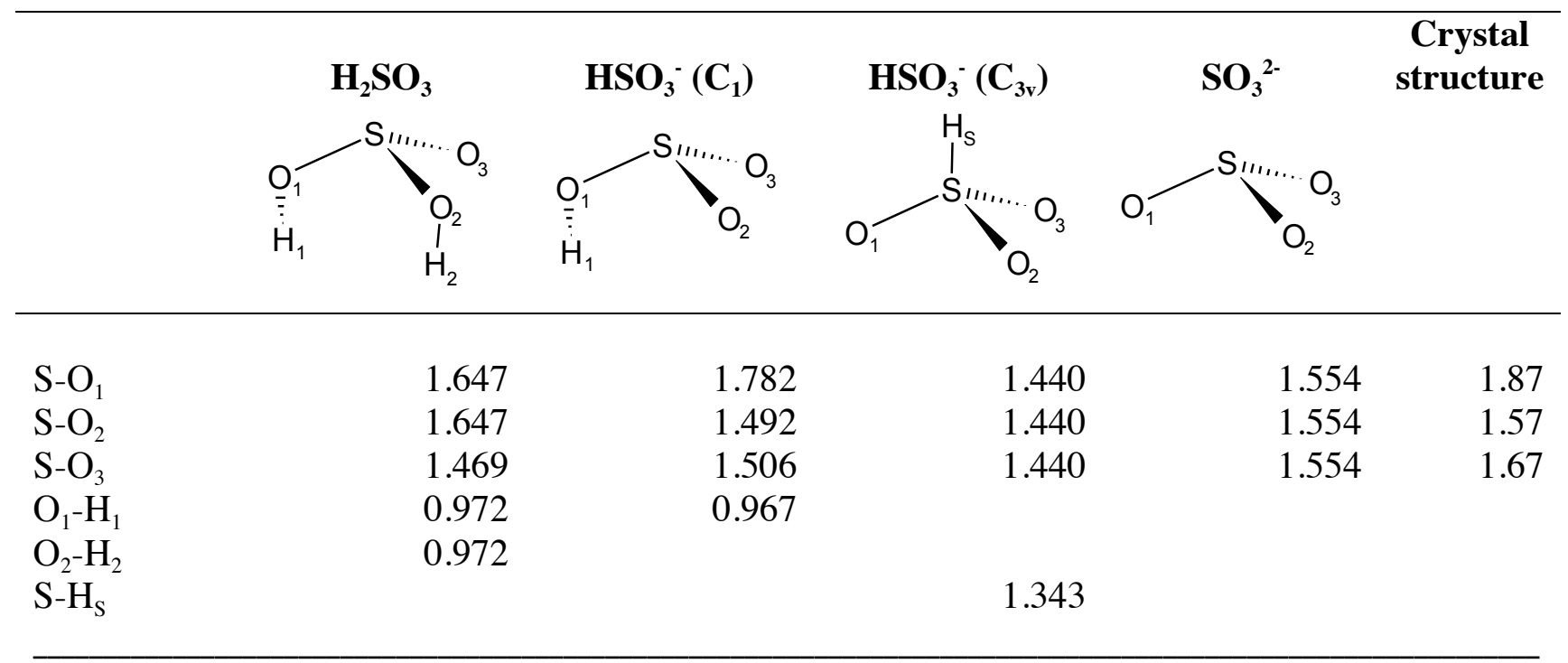




\section{FIGURE LEGENDS}

Figure 1. (A) Details of the active site of native SPU. Atoms are colored accordingly to the atom type. (B) Superimposition of the open (blue ribbons, 4CEU) and closed (yellow ribbons, 3UBP) conformation of the flexible flap. Ni(II) ions are shown as green spheres. The $\alpha$ Cys 322 side chain is reported as "sticks". (C) Multiple sequence alignment of the flap region of the ureases for which a crystal structure is available: SPU, Klebsiella aerogenes urease (KAU), Helicobacter pylori urease (HPU), jack bean urease (JBU), and pigeon pea urease (PPU). The position of SPU $\alpha$ Cys322 and $\alpha$ His323 are in red, while the $\alpha$-helices are highlighted in yellow. The asterisks indicate the fully conserved amino acids.

Figure 2. Typical plots of thermal power of $S$.pasteurii urease activity as a function of time in M1 experiments (A) at $\mathrm{pH} 7.0$ (red line), $\mathrm{pH} 7.5$ (orange line) and $\mathrm{pH} 8.0$ (blue line), and in M2 experiments at $\mathrm{pH} 7.5$ in the presence of $0.02 \mathrm{mM}$ (blue line) and $1.6 \mathrm{mM}$ (red line) sodium sulfite (B). Experimental conditions are described in Materials and Methods.

Figure 3. Atomic model of the active site of sulfite-bound Sporosarcina pasteurii urease (PDB code 5A6T). In panel (A), the nickel-coordination environment is shown superimposed on the final $2 \mathrm{~F}_{\mathrm{o}}-\mathrm{F}_{\mathrm{c}}$ electron density map contoured at $1.5 \sigma$ (cyan). In panel $(\mathbf{B})$, the unbiased electron density map calculated with Fourier coefficients $F_{o}-F_{c}$ and phases derived from the model before the atoms corresponding to $\mathrm{S}, \mathrm{O}(1), \mathrm{O}(2)$, and $\mathrm{O}(\mathrm{B})$ of sulfite were added, is shown contoured at $3 \sigma$ (magenta). The carbon, nitrogen, oxygen, sulfur and nickel atoms are grey, blue, red, yellow and green, respectively.

Figure 4. Crystallographic structural model for the active site obtained for the sulfite-bound Sporosarcina pasteurii urease (PDB code 5A6T). The carbon, nitrogen, oxygen, sulfur and nickel atoms are grey, blue, red, yellow and green, respectively. Putative H-bonds are shown as thin blue lines. Spheres are drawn using the relative atomic radii values in CrystalMaker. 
A

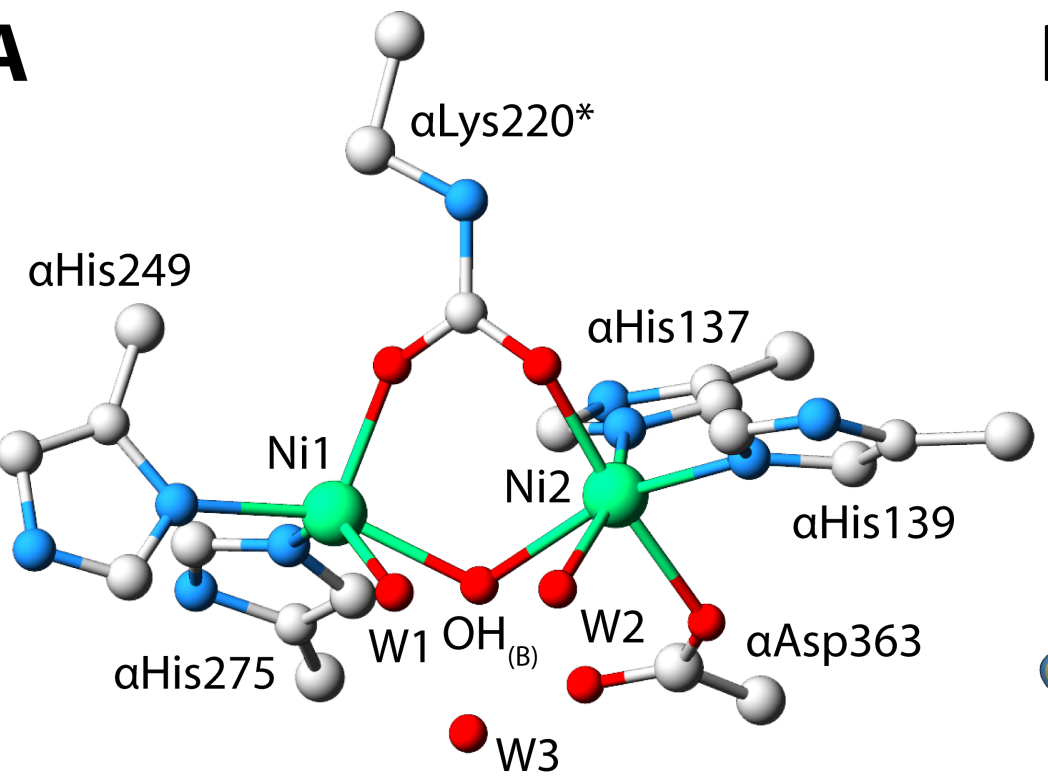

C

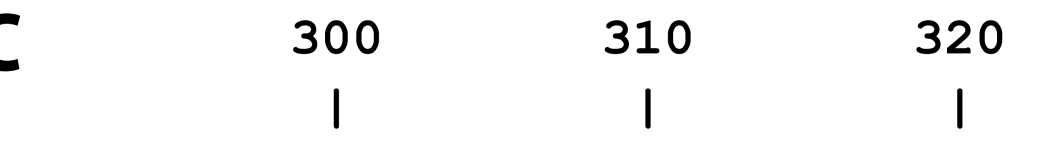

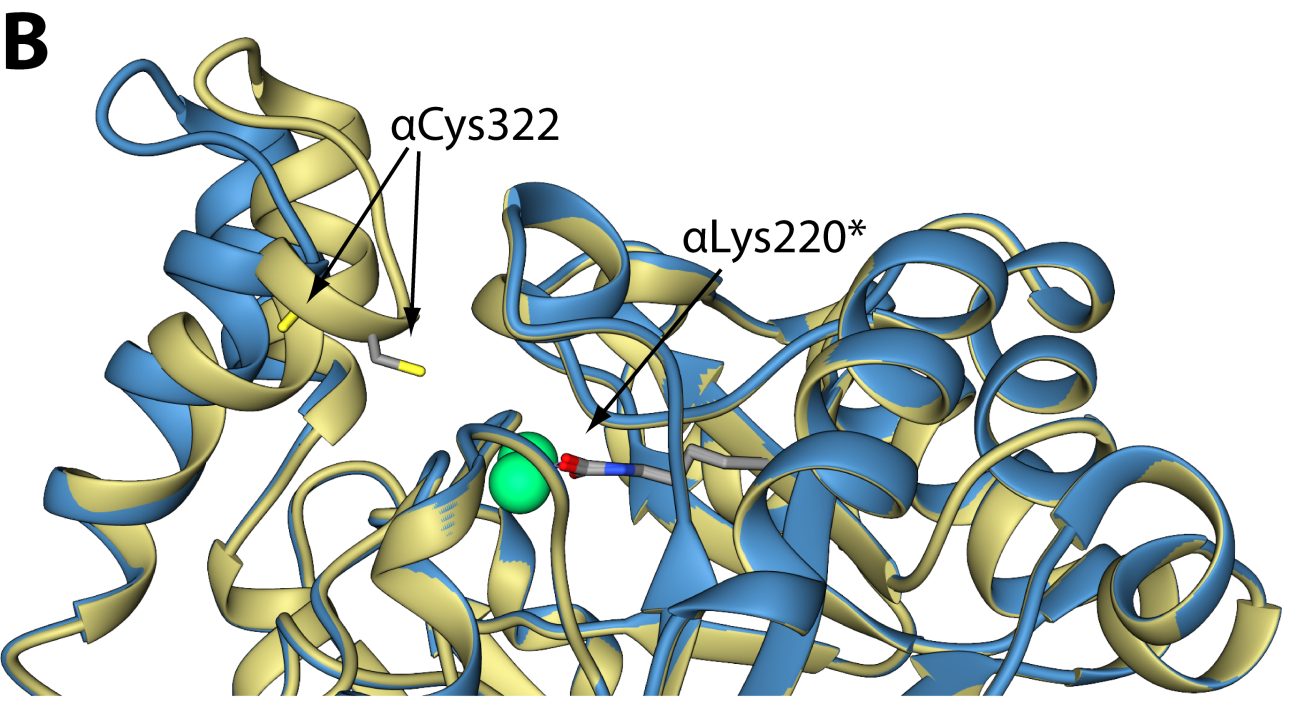

330 340 1
350

SPU 300 ...STNPTRPFTVNTIDEHLDMLMVCHHLKQNIPEDVAFADSRIRPETIAAEDILHDL... 354

KAU 297 ...STNPTLPYTLNTIDEHLDMLMVCHHLDPDIAEDVAFAESRIRRETIAAEDVLHDL... 351

HPU 299 ...STNPTIPFTVNTEAEHMDMLMVCHHLDKSIKEDVQFADSRIRPQTIAAEDTLHDM... 353

JBU 570 ...STNPTRPLTSNTIDEHLDMLMVCHHLDREIPEDLAFAHSRIRKKTIAAEDVLNDI... 624

PPU 570 ...STNPTRPLTSNTIDEHVDMIMVCHHLDANIAEDVAFSASRIREATIAAEDILHDM... 624

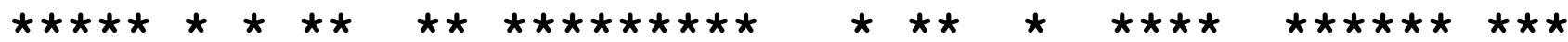


Figure 2
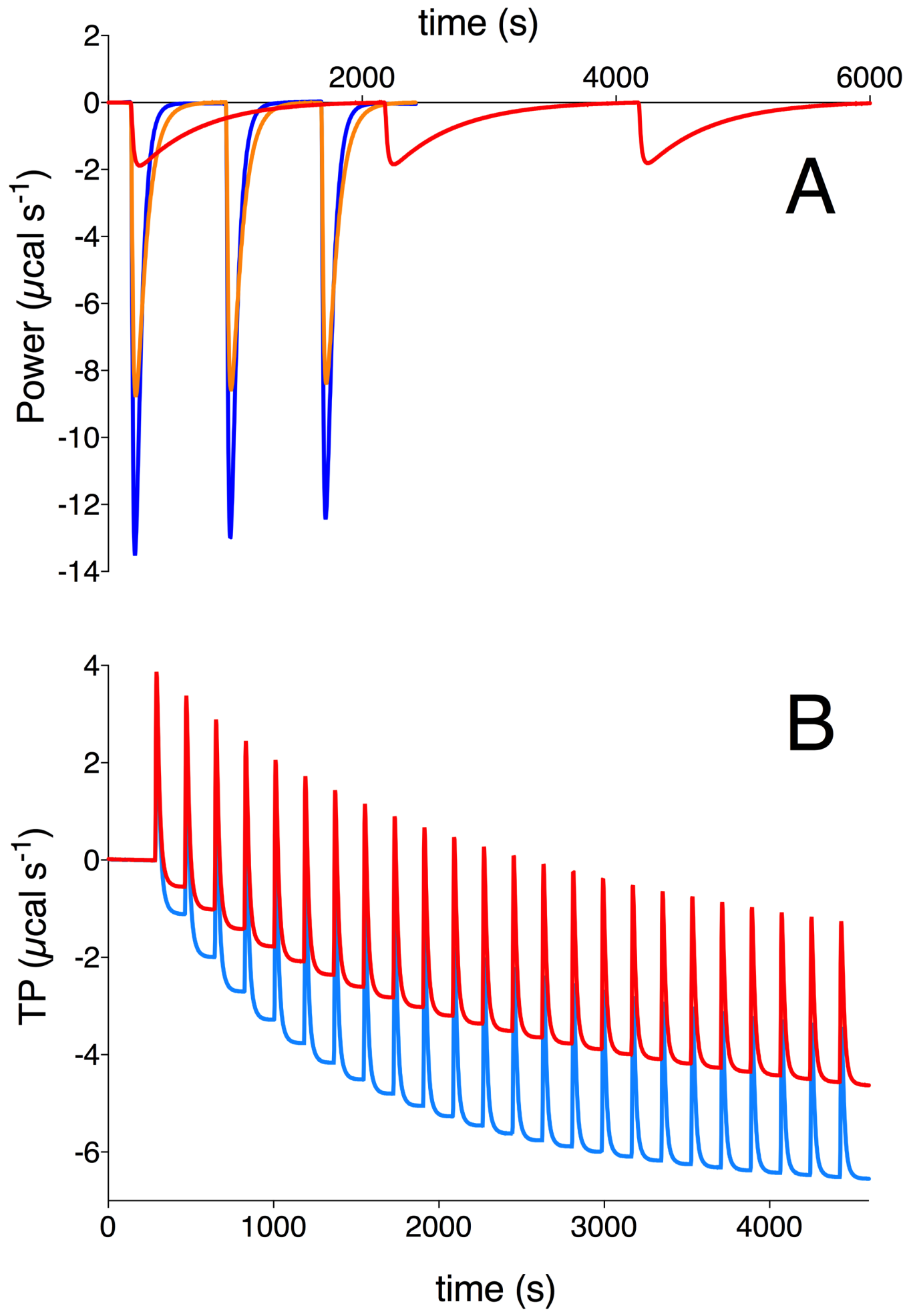
Figure 3

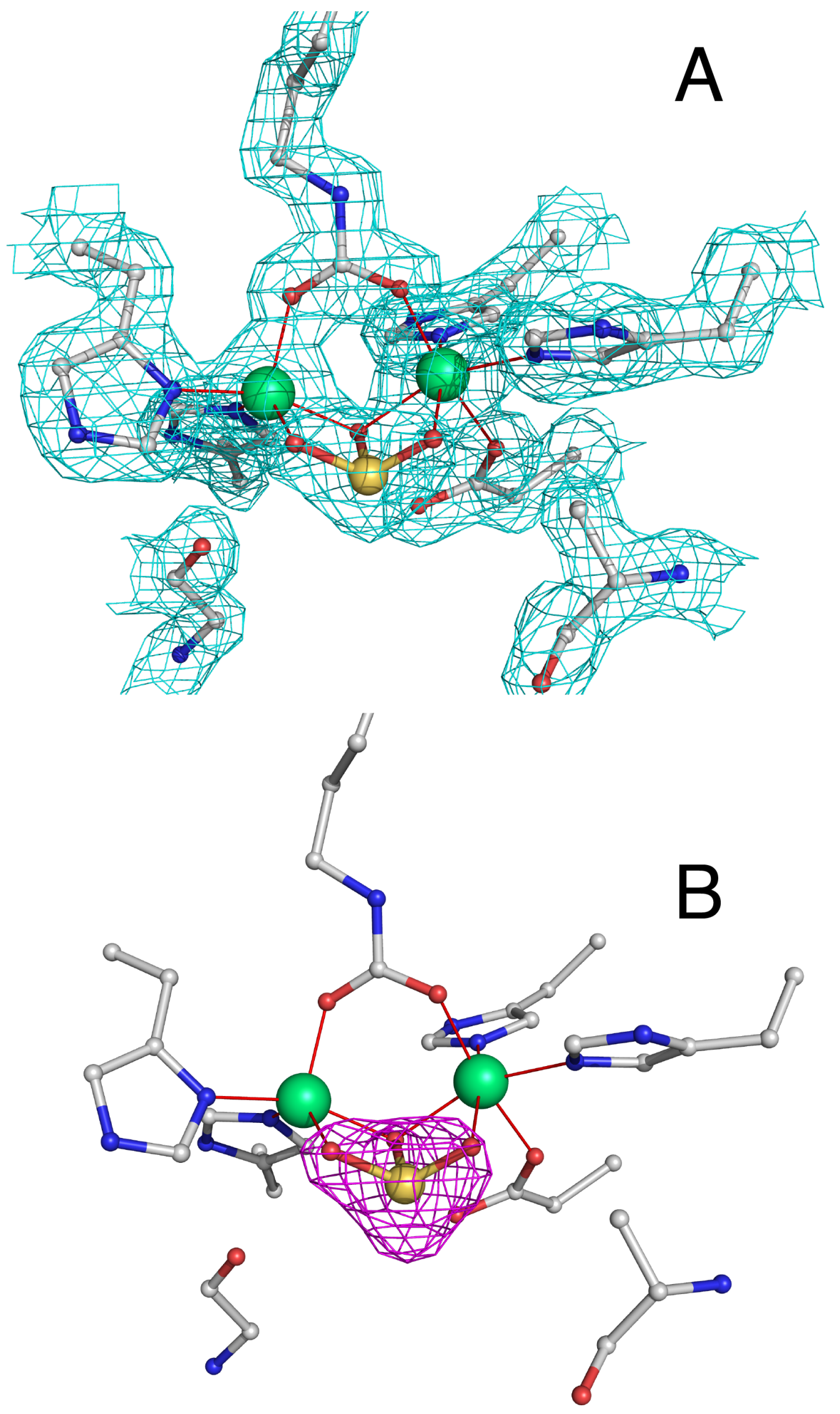


Figure 4

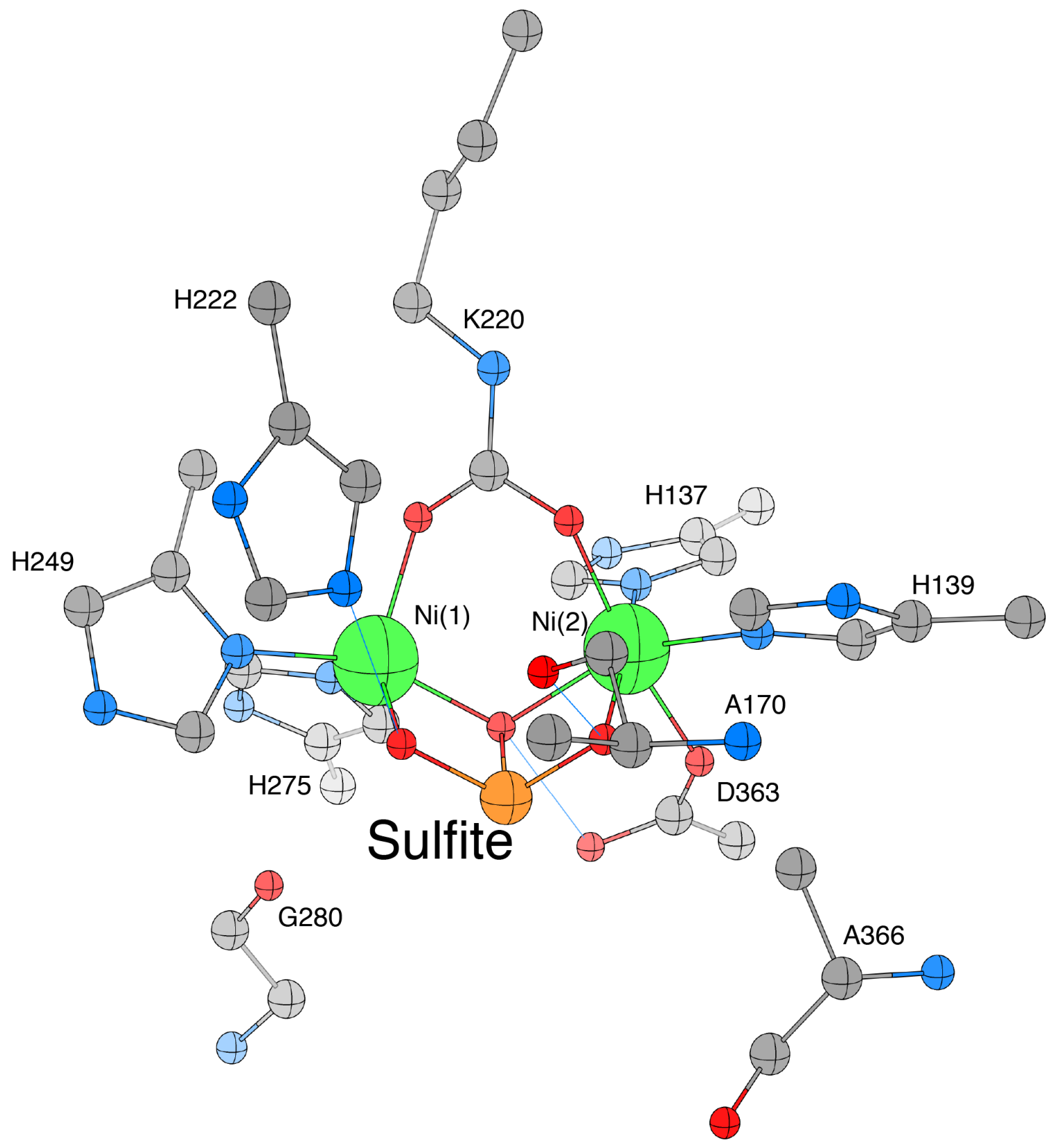

